
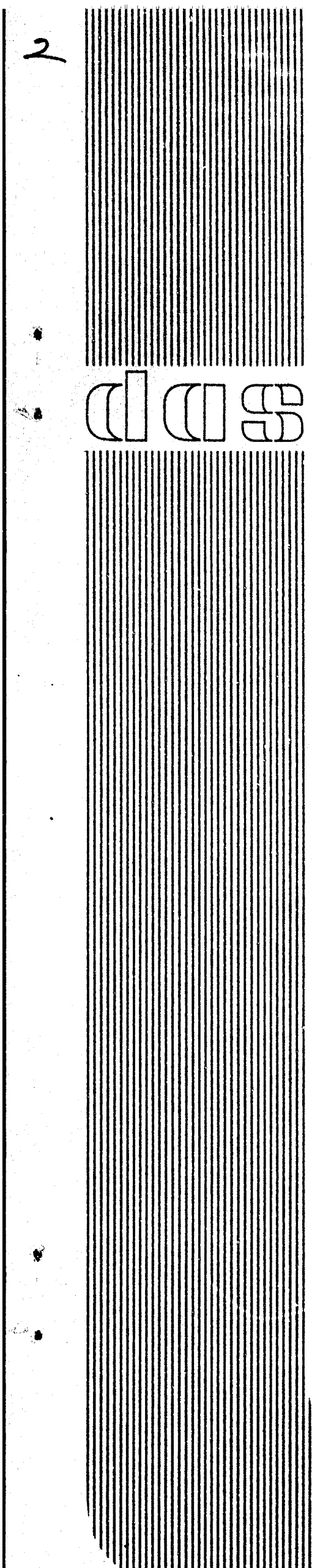

May 1993
BNL-49158

INFORMAL REPORT

V. M. Fthenakis, S. C. Morris and P. D. Moskowitz

The -1,

GUIDELINES FOR ACCIDENT PREVENTION ANE $S T$ I AUG 061803 EMERGENCY PREPAREDNESS

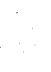
BIOMEDICAL AND ENVIRONMENTAL ASSESSMENT GROUP
ANAL YTICAL SCIENCES DIVISION

DEPARTMENT OF APPLIED SCIENCE

BROOKHAVEN NATIONAL LABORATORY UPTON, LONG ISLAND, NEW YORK 11973

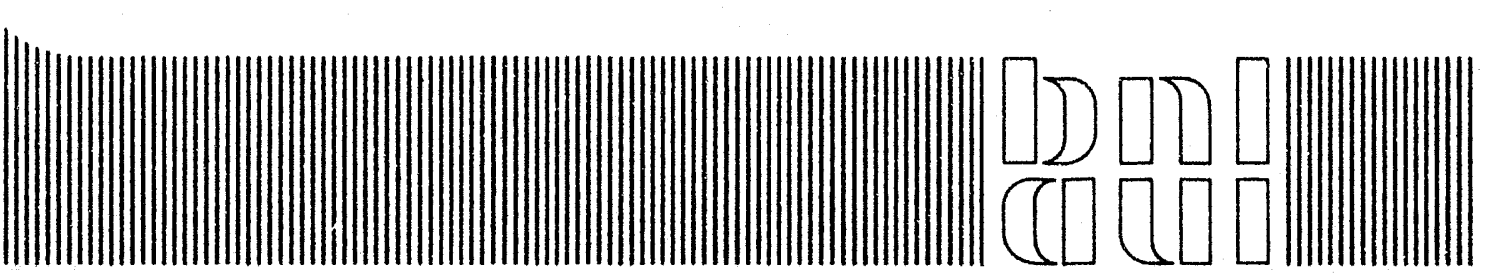




\title{
Guidelines For Accident Prevention and Emergency PREPAREDNESS
}

V.M. Fthenakis, S.C. Morris and P.D. Moskowitz

May 1993

\author{
BIOMEDICAL AND ENVIRONMENTAL ASSESSMENT GROUP \\ ANALYTICAL SCIENCES DIVISION \\ DEPARTMENT OF APPLIED SCIENCE \\ BROOKHAVEN NATIONAL LABORATORY \\ ASSOCIATED UNIVERSITIES, INC.
}

Under Contract No. DE-AC02-76CH00016 with the U.S. Department of Energy MASTER 


\section{DISCLAIMER}

This report was prepared as an account of work sponsored by an agency of the United States Government. Neither the United States Government nor any agency thereof, nor any of their employees, not any of their contractors, sub- contractors, or their employees, makes any warranty, express or implied, or assumes any legal liability or responsibility for the accuracy, completeness, or usefulness of any information, apparatus, product, or process disclosed, or represents that its use wculd not infringe privately owned rights. Reference herein to any specific commercial product, process, or service by trade name, trademark, manufacturer, or otherwise, does not necessarily constitute or imply its endorsement, recommendation, or favoring by the United States Government or any agency, contractor, or subcontractor thereof. The views and opinions of authors expressed herein do not necessarily state or reflect those of the United States Government or any agency, contractor or subcontractor thereof. 


\title{
Guidelines For Accident Prevention and Emergency Preparedness
}

\author{
V.M. Fthenakis, S.C. Morris and P.D. Moskowitz
}

\section{INTRODUCTION}

This chapter reviews recent developments in the guidelines on chemical accident prevention, risk assessrinent, and management of chemical emergencies, principally in the United States arid Europe, and discusses aspects of their application to developing countries. Such guidelines are either in the form of laws or regulations promulgated by governments, or of recommendations from international, professional, or non governmental organizations. In many cases, these guidelines specify lists of materials of concern; methods for evaluating safe usage of these materials; recommend areas of responsibility for different organizations; procedures to be included in planning, evaluation, and response; and appropriate levels of training for different classes of workers. Guidelines frequently address the right of communities to be informed of potential hazards and address ways for them to participate in planning and decision making.

\section{UNITED STATES}

\subsection{Chemical Accident Prevention}

\subsubsection{Federal Regulations}

Shortly after the tragedy in Bhopal, the EPA established a chemical emergency preparedness and prevention program to address the concerns about the possibility of such a major accident happening in the United States. About the same time, the Chemical 
Manufacturers Association (CMA) began implementing its Community Awareness and Emergency Response (CAER) program.

To this end, the Emergency Planning and Community Right-to-Know Act of 1986, ["Title III" of the Superfund Amendments and Reauthorization Act (SARA)], was also enacted. Although SARA Title III, does not address prevention directly, it paves the way for the exchange of information and communication between the facility and the community. According to the EPA, effective chemical accident prevention, along with effective emergency planning and response, occurs when information about risk, prevention, past accidents, "near-misses," and response is shared across the industry, labor, the community, environmental groups, and other stakeholders (Matthiessen, 1992). Accidents are prevented when there are comprehensive management "systems" in place specifically designed to ensure that any error, whether it be by a design engineer, mechanic, operator, or manager, does not lead to a catastrophe: in other words, process safety management (PSM) programs.

Several organizations have been trying to make PSM successful and to keep management committed to its implementation. The American Institute of Chemical Engineers (AIChE) Center for Chemical Process Safety (CCPS), along with many chemical corporations, recognized the need for a comprehensive management system and began implementing process safety management programs and publishing guidelines on such programs. The CMA prepared the Responsible Care program to emphasize process safety. The American Petroleum Institute (API) adopted a process safety mariagement approach in "API Recommended Practices 750". The Occupational Safety and Health Administration (OSHA) believed there was a need for minimum standards to protect workers from chemical accidents and prepared its "Process Safety Management of Highly Hazardous Substances" rule. Recently, Congress ensured a federal role for EPA and OSHA in chemical accident prevention under the Clean Air Act Amendments of 1990 (CAAA). The 
CAAA contain provisions for preventing chemical accidents under Title III-Hazardous Air Pollutants.

The provisions for chemical accident prevention relevant to the EPA are in Title III Section 301(r), while the requirements for OSHA are under Title III Section 304.

\section{osha - Chemical Process Safety management}

The CAAA, mandated that OSHA, under the OSHA Act of 1970, promulgates a chemical process safety standara to prevent accidental releases of chemicals that pose a threat to employees. In response to this requirement, OSHA issued the "Process Safety Management of Highly Hazardous Substances", 29 CFR Part 1910.119 (1992). This rule covers more than three million U.S. workers at nearly 25,000 worksites; it primarily affects manufacturing industries, particularly chemicals, transportation, equipment, and fabricated metal products. Other effected sectors include natural gas liquids, gas and sanitary services, and wholesale trade. This rule requires facilities that are handling substances on the OSHA list of highly hazardous chemicals (Table 18.1), in quantities greater than the listed thresholds, to establish all the elements of a process safety management program. Facilities with 10,000 pounds or more of flammable materials that are used above their boiling points, also are affected by OSHA's rule. A process safety management program is comprised of the following fourteen elements:

1) Introduction to Process Safety Management

2) Employee Involvement

3) Process Safety Information

4) Process Hazards Analysis

5) Operating Procedures 
6) Employee Training

7) Contractors

8) Pre-start Safety

9) Mechanical Integrity

10) Non-routine Work Permits

11) Managing Change

12) Incident Investigation

13) Emergency Preparedness, and

14) Compliance Audits

The following are highlights of compliance requirements and recommendations from Appendix C of the OSHA rule (29 CFR Part 1910, 1992; Auger, 1992):

Introduction to Process Safety Management

An effective process safety requires a systematic approach to evaluating various levels of defense to prevent or mitigate the release of hazardous chemicals. OSHA believes that process safety management in the form of proactive hazard identification, evaluation and mitigation or prevention of chemical releases will have a positive effect on the safety of employees and also offer other potential benefits (e.g., increased productivity). For small business which may have limited resources to implement process safety management options, OSHA suggests alternative ways of decreasing the risks associated with highly hazardous chemicals at their workplaces, such as reducing the inventory of the chemical or distributing storage to several isolated locations. 


\section{Employee Involvement Participation in Process Safety-}

Section 304 of the CAAA states that employers are to consult with their employees regarding the employers effort in the development and implementation of the process safety management and hazard assessment. Employers are also required to train and educate their employees and to inform affected employees of the findings from incident investigations.

Process Safety Information - Employers must provide written information regarding process technology, equipment used, and hazards posed processes utilizing hazardous chemicals. Required information includes, but is not limited to: material safety data sheets, permissible exposure limits; potential risks from inadvertent mixing of materials; process flow diagrams; safe temperature and pressure limits; and equipment design codes.

Process Hazard Analysis - A process hazard analysis (PHA) is one of the most important elements of the process safety management program. The PHA focuses on equipment, instrumentation, utilities, human actions and external factors that might impact the process. OSHA prescribes a team approach, preferably with members from various disciplines. Team must include members expert in the scientific process and methodology in use, whether or not this expertise is available on site. The team's findings must be addressed formally and resolved in a timely manner. The analyses must be performed in priority order, with 25 percent of them completed by May 26, 1994, and an additional 24 percent completed each year until all are completed no later than May 26, 1997. Analyses must be updated every five years. 
Operating Procedures - Operating procedures describe tasks to be performed, data to be recorded, operating conditions samples to be collected, and safety and health precautions. Operating procedures should be reviewed by engineering and operating personnel. Such procedures must be complete and comprehensive; if workers are not fluent in English, procedures need to be written in a second language understood by the workers.

Employee Training -All employees involved with highly hazardous chemicals, including maintenance and contractor employees, must be formally trained in the appropriate operating procedures. Refresher training will be required (e.g., at least every 3 years) and detailed documentation of each employee's training experience is required. Careful consideration must be given to provide current and updated training. For example, if changes are made to a process, impacted employees must be re-trained and understand the effect of the changes on their job tasks.

Contractors - This provision is basically designed to emphasize that standards are to cover all, including contract employees. Employers who use contractors to perform work in and around processes that involve highly hazardous chemicals, will need to establish a screening process for hiring contractors who accomplish their tasks without compromising safety.

Pre-Startup Safety - For new processes, a PHA is helpful in improving the reliability of design and construction of the process. The recommendations of the PHA must be addressed, and procedures and training must be completed before startup. 
Mechanical Integrity - This provision sets the requirement for periodic inspection, testing and quality assurance standards for equipment used in storage, processing or handling of highly hazardous chemicals. A mechanical integrity program must be in place to assure the continued integrity of such equipment. The rule refers to primary line of defense (e.g. containment, controlled release through scrubbers or flares), and secondary systems (e.g., fire protection, water spray, dikes), systems which are discussed throughout this book. The integrity of these systems should be assured through preventive maintenance and testing.

Hot Work Permit - Non routine work which is conducted in the vicinity of covered by the standard process, has to be formally approved. The employer must issue a permit for such work and ensure that certain prevention and protection measures are satisfied.

Management of Change - Temporary changes have causes a number of accidents over the years, mainly because personnel was not fully aware of the impact such changes made to an operation. Management of change covers changes in process technology and changes to equipment and instrumentation. Employers are required to establish means and methods to detect both technical and mechanical changes and to provide written documentation and authorization of the changes.

Incident Investigation - Any incident which resulted or could have been resulted in a hazardous chemical release must be investigated within 48 hours by a team assembled by the employer. A multi-disciplinary team is better able to gather the 
facts of the event. A report including contributing factors and suggestions for corrective actions must be submitted. The report, its findings and recommendations are to be shared with those who can benefit from the information.

Emergency Preparedness - Employers must address what actions employees are to take when there is an accidental release of highly hazardous chemical. Employers at the minimum must have an emergency action plan which will facilitate the prompt evacuation of employees during an accident. This means that they should have an emergency action plan, including escape route, procedures and assignment. This plan will be activated by an alarm system, to alert employees when to evacuate. Employees who are physically impaired must have the necessary support and assistance to get them to a safe zone as well.

Compliance Audits - Employers must audit their operations to ensure compliance with the provisions of the rule. This self-evaluation can help employers measure the continuing effectiveness of their safety management systems. Reporting procedures must be established, the findings of the audit must be followed and deficiencies corrected.

The centerpiece of the new standard is process hazard analysis. It offers an integrated approach to chemical safety by putting the focus on a comprehensive management program. The standard details the elements and performance measures so that each facility can develop the most appropriate management system to meet its particular needs. Given the large number and diversity of the industries affected by 1919.119, this new standard is necessarily performance based, giving sites some degree 
of flexibility in meeting their responsibilities. OSHA will determine compliance by comparing a facility's performance with the standards set forth in the regulation in each of the thirteen interrelated areas.

\section{EPA REQUIREMENTS}

Under the CAAA, Section 112(r), the EPA has also specific duties relative to the prevention of accidental releases. In general, EPA is required to develop a list of chemicals and a Risk Management Plan. EPA believes these same elements outlined in OSHA's new standard are necessary to prevent chemical accidents that affect the general public and the environment. EPA and OSHA recognize this overlap and are working closely on the list of chemicals, thresholds and key elements to avoid confusion and duplicate rule makings (Matthiessen, 1992). EPA also believes that the OSHA standard can provide a strong foundation for EPA efforts required by Section $112(r)$ as described below:

\section{General Duty}

Congress recognized that industry is ultimately responsible for the prevention of chemical accidents. Consequently, the first requirement in the chemical accident prevention provisions of the statute is a general duty clause for owners and operators of fixed facilities producing, handling or storing any listed substances to:

Identify hazards that may result from accidental releases

Design, operate and maintain safe facilities

Minimize the consequences of accidental releases 


\section{List of Substances}

The EPA is required to develop an initial list of at least 100 substances and corresponding threshold quantities that will be the focus of chemical accident prevention regulations. The list must be promulgated no later than November 15, 1992 and address "substances which, in an accidental release, are known to cause or may reasonably be anticipated to cause death, injury, or serious adverse effects to human health or the environment." The EPA may use the list of 402 Extremely Hazardous Substances published under SARA Title III and must also include the 16 extremely hazardous substances listed in the CAAA (Table 18-2).

\section{Chemical Safety and Hazard Investigation Board}

The Prevention of Accidental Releases plan in the CAAA, also establishes a Chemical Safety and Hazard Investigations Board with the responsibility to "investigate or cause to be investigated, accidental releases resulting in a fatality, serious injury or substantial property damages." The Board will be consisted of five-members to be nominated by the President and confirmed by the Congress. The safety board may establish reporting requirements and is required to report to Congress and to make recommendations to the EPA and OSHA on chemical accident prevention.

\section{Prevention Regulations}

By November 1993, the EPA must promulgate "reasonable regulations and guidance" for the prevention, detection and response to accidental releases by facility owners or operators. Facilities having substances on the list established above in quantities greater than the threshold level, will be required to comply with EPA rules for the "use, operation, repair, replacement, and maintenance of equipment to monitor, detect, inspect, and control releases." Such regulations must also require owners and operators to "prepare and implement a risk management plan to detect and prevent or minimize 
accidental releases of listed substances and to provide a prompt emergency response to any such releases."

A risk management plan must include the following:

Hazard assessment - A five-year release history and an evaluation of the worst cease accidental release scenarios including potential release quantities and potential exposures to populations living downwind;

A program for prevention of accidental releases; and

A response program for specific actions to be taken in the event of an accidental release, including employee training for response, emergency health care and informing the public.

Risk management plans must be registered with EPA and submitted to the state where the facility is located, local emergency planning or response agencies, the Chemical Safety and Hazard Investigation Board, and also made available to the public.

The EPA believes that the elements of good process safety management, as required by OSHA, form the basis of the prevention program part of the risk management plan (Matthiesen, 1992). The major difference between the OSHA and EPA requirements would be that process hazard analyses must assess the impact of chemical accidents on the general public and the environment.

EPA also is granted new authority to take action in the event of accidental releases. The CAA authorizes EPA, in case where there may be imminent and substantial risk due to the release of an extremely hazardous substance, to ".. secure such relief as may be necessary to abate such danger or threat...". 


\subsubsection{State Prevention Statures}

In addition to federal regulations, the states of Delaware, New Jersey, and California, as well as several local governments, have regulations that deal with chemical accident prevention. These regulations list threshold planning quantities for specific chemicals; if the quantity of a chemical on-site exceeds the threshold quantity, the facility must notify the regulating agency, and prepare a risk management plan. These risk management plans should provide a description of management program to prevent accidents, the results of a formal hazard assessment, design safety reviews, standard operating and preventing maintenance procedures, risk assessment, and response planning. New Jersey and California require a facility to submit a complete risk management plan to both the state and local goverriment for approval. Delaware requires that facilities develop a risk management plan and make it available to inspectors during site inspections. In New Jersey and Delaware, every facility that meets or exceeds a specified threshold quantity, must develop a plan. In California, it is up to the local implementing agency (e.g., fire department to determine whether a plan is required.

The new OSHA-Chemical Process Safety Management (CPSM) regulation will have an impact on these state CPSM programs. Implementation of the CPSM standard in New Jersey and Delaware will depend on OSHA's acceptance of the existing state level Risk Management Programs (RMP). Facilities in these two states have invested significant resources into the development and implementation of the state RMPs and would only need minor modification to comply with the federal standard. California has an existing Risk Management and Prevention program (RMPP), but is also planning to adopt a state level OSHA CPSM program. The state CPSM program will have similar requirements but different compliance deadlines than the Federal standard. For the other states which do not have CPSM programs in place, implementation of the OSHA's standard will be determined according to the state's authority to adopt and enforce the federal standard. 
There are 23 states with authority to adopt and enforce the federal standard; for those an active and closely monitored implementation approach is expected. For the remaining 25 states with no authority to adopt the federal standard, implementation will be at the federal level (Edwards et al, 1992).

\subsection{Minimum Reportable Amounts of Releases}

Guidelines frequently address minimal amounts of each hazardous material, above which action is required. These amounts may apply to stocks or to releases. Four US laws set minimal reportable amounts for releases; these are described below.

\section{1) CERCLA Hazardous Substances}

The Comprehensive Environmental Response, Compensation, and Liability Act of 1980 (CERCLA or Superfund) requires reporting of releases into the environment of over 700 hazardous substances in quantities higher than a designated reportable quantity (RQ). For several compounds these RQs correspond to a 24-hr release of only 1 pound. Designation of these substances and their reportable quantities may be based on aquatic or mammalian toxicity, ignitability, reactivity, and carcinogenicity. Substances and RQs are listed in 40 CFR Part 302, Table 302.4. The report must be made via a 24-hour telephone hotline operated by the National Response Center in Washington DC. Failure to do so may result in a fine of up to $\$ 10,000$ and imprisonment of up to one year.

Section 102 of CERCLA provides the EPA administrator with authority to promulgate regulations establishing quantities of hazardous substances which must be reported. In the absence of such regulations, reportable quantities are defined as either those established based on Section 311(b) of the Federal Water Pollution Control Act, or, for other compounds, a quantity of 1 pound. 


\section{2) SARA - Title III}

The Emergency Planning and Community Right-to-Know Act of 1986, often called "Title III" of the Superfund Amendments and Reauthorization Act (SARA), has four major provisions: i) Emergency planning (Sections 301-303), ii) emergency notification (Section 304), iii) community right-to-know reporting requirements (Section 311-312), and iv) toxic chemical releases reporting-emissions inventory (Section 313).

The emergency planning sections are designed to assist state and local government emergency preparedness and response capabilities through better coordination and planning. The emergency notification section requires all facilities that produce, use, or store one or more hazardous chemicals to immediately notify designated authorities in case of a release in excess of the reportable quantity for this substance. The community right-to-know (Section 311) requires any facility which must have material safety sheets (MSDS) under the OSHA hazard communication regulations, to submit either copies of the MSDSs, or a list of those chemicals to local authorities. Reporting requirements apply to chemicals in quantities above designated Threshold Planning Quantities (TPQ). The presence of EHSs in quantities above the Threshold Planning Quantity (TPQ), requires certain emergency planning activities to be conducted. These substances are listed in 40 CFR, Part 355, Appendices $A$ and $B$. If a final $R Q$ has not been assigned under CERCLA to a chemical listed under section 302 , a statutory $R Q$ of 1 pound applies for reporting.

SARA Title III requires facilities to notify State emergency Response Commissions (SERCs) when Extremely Hazardous Substances (EHSs) are present and to participate with Local Emergency Planning Committees (LEPCs) to plan and prepare for chemical emergencies. Facilities are also required to provide critical information on the identity, quantity and location on-site of EHSs to the community. Also under Title III's community 
right to know, emissions or releases of chemicals listed under section 313 , must be reported annually.

A consolidated list of all hazardous substances included in CERCLA, SARA Section 302, and SARA Section 313, can be found elsewhere (EPA, 1991a).

\section{3) Hazardous Materials Transportation Act}

Releases during transport of hazardous material are subject to reporting under the Hazardous Materials Transportation Act. These substances and their reportable quantities are listed in the Appendix to 49 CFR 172.101.

\section{4) Clean Water Act}

Releases of hazardous substances and oil to navigable waters of the United States (this legal term includes most substantial waters in the US, including territorial seas and rivers) must be reported under the Clean Water Act. Hazardous substances are listed in 40 CFR 117.3, and are also Superfund hazardous substances.

\section{EUROPE}

Guidelines for emergency preparedness and response often grow out of lessons learned from past disasters. Major accidents in 1974 in Flixborough, U.K., In Holland in 1975 the dioxin release near Seveso, Italy, in 1976, led to the European Community's first comprehensive rules, in 1982, on major-accident hazards of industrial activities, known as the Seveso directive (EEC, 1982). The directive was further strengthened in 1987 and 1988 (EEC, 1987; 1988). Although these amendments stemmed from the 1986 Sandoz 
warehouse fire in Schweizerhalle, Switzerland, as Schwabach (1989) points out, they do not apply to Switzerland, since it is not an EC member.

The Seveso directive established requirements to be adopted by member states. Manufacturers are required (1) to identify major accident hazards; (2) to take measures to prevent major accidents; (3) to limit the potential consequences in the event of an accident; and (4) to notify authorities of potential hazards, preventive measures taken, and the occurrence of any major accident. The directive identified threshold quantities of dangerous substances on the basis of toxicity, flammability or explosiveness. Classes of these materials are given in Table 1 . Countries are required to appoint authorities competent to (1) receive the notification from manufacturers; (2) examine information provided; (3) assure emergency plans were prepared; and (4) organize inspections or other control measures.

The World Health Organization Regional Office for Europe developed a manual of guidelines for disaster preparedness. The manual covers preparation, implementation, and rehabilitation phases and includes information needed, procedures, administrative action, organization, management, and allocation of resources. Continuity is provided by an inhouse task force and an outside group of assessors made up of experts from Member States and from the WHO Regional Office (Jones, 1989).

Non-EEC countries have their own safety regulations. Sweden, for example, regulates the control of several chemicals according to the Swedish Act on Chemical Products. Under this Act, manufacturers and importers of chemical products are responsible for providing hazard information and safety advice for those using the chemicals. In addition, there is a general obligation to take precautions to prevent or minimize harm to human beings or the environment; such precautions include substitution of chemicals with less hazardous substitutes. 


\section{Less DeVELoped COUNTRIES}

Less developed countries face special problems preparing for and responding to industrial accidents. Existing industrial plants may be technologically obsolete, not incorporating modern safety features. Population density and proximity of settlements to industrial sites often complicates planning. Transportation, communication, and other physical infrastructure are often weak. Regulatory bodies may not be up-to-date with technological advances, are often underfunded, and lack needed equipment and resources. Even scientific knowledge of the effect of hazardous chemicals may not extend to some less developed countries. Environmental health criteria derived from experience in temperate regions may not be completely applicable in tropical or semi-tropical countries. Guidelines for industrial accidents in less developed countries have been developed by the World Bank and the World Health Organization. These are described below.

\section{INTERNATIONAL ORGANIZATIONS}

International Labor Organization. Guidelines of the ILO were given in a working paper produced by a tripartite (employers, labor, government) meeting (ILO, 1985). They include methods of hazard identification, characterization, and management, and emergency planning for workers and the public. They encourage nations to establish a regulatory program and provide a framework for such programs. Much of the approach drew on the earlier EEC guidelines, which listed hazardous substances with threshold quantities above which facilities must notify regulatory authorities. Guidelines are also provided for identification of very toxic, flammable, and explosive substance for this purpose. Although specific for toxicity and flammability, they allow considerable interpretation on the chemical and physical conditions that might increase the risk of a major accident. 
The ILO guidelines place the fundamental responsibility for ensuring safe operation on manufacturers, and indicate that they conduct their own hazard surveys in addition to those by the regulatory authority. Manufacturers must take all necessary measures to prevent major accidents and to limit their consequences. The manufacturers' responsibility is twofold: (1) to identify hazards, inform and train personnel, prevent accidents, minimize their consequences and prove compliance to the competent authority at anytime; and (2) to notify competent authorities if specific chemicals from among those identified as hazardous are present in storage, processing, manufacture, or produced as residues or by-products in amounts over the threshold. Hazard management is achieved through design standards, protective devices, maintenance, inspecting and testing, emergency planning and training. Considerable administrative guidance is provided, but not technical guidance. For example, guidelines for the integrity of pressurized systems include recommendations that inspection, preventive maintenance and standby equipment for pumps are necessary only if failure could create a hazardous situation. This determination is made by professionals on the staff of the manufacturer with oversight by the regulatory agency.

World Bank. In financing industrial programs in developing countries, the World Bank evaluates the adequacy and effectiveness of measures to control major hazards affecting public health and the environment outside the plant boundary. The World Bank guidelines (World Bank, 1985a) were based heavily on the earlier EEC and UK guidelines (H\&SE, 1984), but are supplemented with a technical manual (World Bank, 1985b) and microcomputer software that includes computer codes of recommended consequence models (Technica, 1986). Guidelines and manual aim at developers of industrial projects in developing countries. The accompanying Manual of Industrial Hazard Assessment Techniques (World Bank, 1985b) provides a framework for the structured identification of such hazards. The basic procedures included in this manual guide engineers and safety analysts through a series of steps to identify basic failure modes, estimate the quantities of 
material released, and calculate the impacts of these materials on plant equipment and personnel or the surrounding population and the environment. Attention is also focused on approaches for estimating event frequencies and for examining the need for remedial measures. Methods are available for relating event frequencies to consequences, but are not covered in this manual.

The guidelines specify that a major hazard assessment be conducted if threshold quantities are exceeded. These thresholds refer to (1) very acutely toxic substances; (2) other toxic substances; (3) highly reactive substances and explosives; and (4) flammable substances. These classes are generally defined according to EEC criteria. A major hazard assessment is required irrespective of the quantity involved for three categories considered particularly dangerous: (1) very acutely toxic substances; (2) highly reactive substances (except for specifically named compounds); and (3) flammable liquids at high temperature and pressure. Other toxic substances require a major hazard assessment when quantities exceed 1 tone (except for specifically named substances with higher threshold quantities). Flammable gases and highly flammable liquids have threshold quantities of 15 and 10,000 tones respectively. The World Bank manual provides the framework for the assessment. It focuses on possible causes of a release and on analysis of the resulting consequences. Representative failures and associated releases for components (i.e., pipes, flexible connections, filters, valves, pressure/process vessels, pumps, compressors, storage tanks, storage vessels, and flare vents) are given. Tree diagrams guide the analyst to a selected set of transport and effects models that are based on properties of the discharged material (i.e., phase, pressure, temperature, flammability, and toxicity). The full structure and models are included in the WHAZAN computer software (Technica, 1986). 


\section{World Health Organization}

The WHO was instrumental in recommending guidelines for less developed countries (Krishna et al., 1990). Table 3 summarizes these guidelines.

\section{Comparison OF EPA, ILO AND WORLD BANK GUIDELINES}

Guidelines may vary in technical detail or specific focus depending on intended users. Guidelines aimed at community groups, for example, will be much different in content than those aimed at consulting engineers.

A comparison of EPA, International Labor Organization (ILO), and World Bank guidelines for risk identification, assessment and management of chemical emergencies (Morris et al., 1987) found that they differed principally in the audience addressed, the types of contaminants considered, the sophistication of the release scenario and environmental transport models considered, and the end-point evaluated. Parts of the descriptions of these guidelines given below are taken from this comparison report. EPA guidelines (EPA, 1985) were aimed at community groups, providing approaches that could be used without professional expertisa, but which thus lacked sophistication and could not take into account many factors affecting release. The result was likely to be a burdensome number of cases were likely to be identified as potential hazards that would turn out, upon more detailed investigation, not to pose significant risk. More recent EPA actions, based on the 1990 Amendments to the Clean Air Act, are discussed below.

The ILO (1985) approach was based on the European Community approach, discussed in more detail and updated below. It aimed at government regulatory agencies and industrial firms that are presumed to have professional expertise to conduct detailed analyses, but did not give detailed guidance on how to conduct the analysis. These guidelines contain a 
list of hazardous chemicals with thre'shold quantities for action, a description of responsibilities for each organization, and what is essentially a check list of what must be done in an assessment and analysis of potential major hazards.

The World Bank guidelines are aimed at project developers, who also would have access to professional expertise. It provides essentially an engineering handbook, proscribing detailed methods for analysis of hazards.

\section{REFERENCES}

29 CFR Part 1910, Federal Register, Vol. 57, No. 36, February 24, 1992.

Auger J, Process Safety, Occupational Health and Safety, May 1992, pp. 61-66.

Edwards A. T., McCue M.J and Mulvey N.P., OSHA _ PSM regulatory impact on state programs: New Jersey TCPA case study, presented at the 1992 AIChE Summer National Meeting, Minneapolis, MN, August 10, 1992.

EEC. 1982. Council Directive of 24 June 1982 on the major-accident hazards of certain industrial activities (82/501). Official Journal of the European Community 25 (L230): 1-18.

EEC. 1987. Council Directive of 19 March 1987 amending Directive 82/501/EEC on the major-accident hazards of certain industrial activities. Official Journal of the European Community 30 (L85): 36-37. 
EEC. 1988. Council Directive of 24 November 1988 amending Directive 82/501/EEC on the major-accident hazards of certain industrial activities. Official Journal of the European Community 31 (L336): 14-15.

EPA. 1985. Chemical Emergency Preparedness Program Interim Guidance, U.S. Environmental Protection Agency, Washington, DC.

EPA. 1991a, Title III, List of Lists, EPA 560/4-91-011, January $1991 .$.

H\&SE. 1982. A guide to the notification of installations handling hazardous substances regulations. Health and Safety Series Booklet HS(R) 16. HMSO, London.

H\&SE. 1984. A guide to the control of industrial major accident hazards regulations. Health and Safety Series Booklet HS(R) 21, HMSO, London.

ILO. 1985. Working paper on control of major hazards in industry and prevention of major accidents (MHC/1985/1), International Labour Organization, International Labor Office, Geneva.

Jones, J.T. 1989. Disaster preparedness and relief: development of programs by the World Health Organization, Appendix I in C.R. Krishna Murti, J. Rantanen, and E. Somers.

Prevention of Chemical Accidents and Mitigation of Health Injury Caused by Them. Hemisphere Publishing Corporation, New York.

Krishna Murti, C.R., J. Rantanen, and E. Somers. 1989. Prevention of Chemical Accidents and Mitigation of Health Injury Caused by Them. Hemisphere Publishing Corporation, New York. 
Morris,S.C., P.D. Moskowitz, V.M. Fthenakis, and L.D. Hamilton. 1987. Comparison of EPA, ILO, and World Bank Guidelines for risk identification, assessment, and management of chemical emergencies. Environment International 23: 305-310.

NAS. 1983. Risk Assessment in the Federal Government: Managing the Process. Committee on the Institutional Means for Assessment of Risks to Public Health, National Academy Press, Washington, D.C.

Schwabach, A. 1989. The Sandoz spill: the failure of international law to protect the Rhine from pollution, Ecology Law Quarterly 16: 443-480.

Technica. 1986. WHAZAN User Guide and Theory Manual. Technica International, Westlake Village, California.

World Bank 1985a. World Bank guidelines for identifying analyzing and controlling major hazard installations in developing countries. Office of Environment and Scientific Affairs, World Bank, Washington, DC.

World Bank. 1985b. Manual of Industrial Hazard Assessment Techniques. Office of Environment and Scientific Affairs, World Bank, Washington, DC. 
Table 1. OSHA List of Highly Hazardous Chemicals

\begin{tabular}{|c|c|c|}
\hline CHEMICAL name & CAS* & $T Q^{* \star}$ \\
\hline $\begin{array}{l}\text { Acetaldehyde } \\
\text { Acrolein (2-Propenal) } \\
\text { Acrylyl Chloride } \\
\text { Allylamine } \\
\text { Alkylaluminums } \\
\text { Ammonia, Anhydrous } \\
\text { Ammonia solutions ( }>44 \%\end{array}$ & $\begin{array}{c}75-07-0 \\
107-02-8 \\
814-68-6 \\
107-11-9 \\
\text { varies } \\
7664-41-7\end{array}$ & $\begin{array}{r}2500 \\
150 \\
250 \\
1000 \\
5000 \\
10000\end{array}$ \\
\hline $\begin{array}{l}\text { ammonia by weight } \\
\text { Ammonium Perchlorate } \\
\text { Ammonium Permanganate } \\
\text { Arsine (also called Arsenic }\end{array}$ & $\begin{array}{l}7664-41-7 \\
7790-98-9 \\
7787-36-2\end{array}$ & $\begin{array}{r}15000 \\
7500 \\
7500\end{array}$ \\
\hline $\begin{array}{l}\text { Hydride) } \\
\text { Bis(Chloromethyl) Ether } \\
\text { Boron Trichloride } \\
\text { Boron Trifluoride } \\
\text { Bromine } \\
\text { Bromine Chloride } \\
\text { Bromine Pentafluoride } \\
\text { Bromine Trifluoride } \\
\text { 3-Brumopropyne (also called }\end{array}$ & $\begin{array}{c}7784-42-1 \\
542-34-5 \\
10294-34-5 \\
7637-07-2 \\
7726-95-6 \\
13863-41-7 \\
7789-30-2 \\
7787-71-5\end{array}$ & $\begin{array}{r}100 \\
100 \\
2500 \\
250 \\
1500 \\
1500 \\
2500 \\
15000\end{array}$ \\
\hline $\begin{array}{l}\text { Propargill Bromide) } \\
\text { Butyl Porbenzoate (Tertiary) } \\
\text { Carbonyl Chloride }\end{array}$ & $\begin{array}{l}106-96-7 \\
614-45-9\end{array}$ & $\begin{array}{r}100 \\
7500\end{array}$ \\
\hline $\begin{array}{l}\text { (see Phosgene) } \\
\text { Carbonvl riluoride Cellulose } \\
\text { Nitrate (concentration > } 12.6 \%\end{array}$ & $75-44-5$ & 100 \\
\hline $\begin{array}{l}\text { nitrogen } \\
\text { Chlorine } \\
\text { Chlorine Dioxide } \\
\text { Chlorine Pentrafluoride } \\
\text { Chlorine Trifluoride } \\
\text { Chlorodiethylaluminum } \\
\text { (also called Diethylaluminum }\end{array}$ & $\begin{array}{c}9004-70-0 \\
7782-50-5 \\
10049-04-4 \\
13637-63-3 \\
7790-91-2\end{array}$ & $\begin{array}{r}2500 \\
1500 \\
100 \\
120 \\
1000\end{array}$ \\
\hline $\begin{array}{l}\text { Chloride) } \\
\text { 1-Chiloro-2,4-Dinitrobenzene } \\
\text { Chloromethyl Methyl Ether } \\
\text { Chloropicrin } \\
\text { Chloropicrin and Methyl }\end{array}$ & $\begin{array}{c}96-10-6 \\
97-00-7 \\
107-30-2 \\
76-06-2\end{array}$ & $\begin{array}{r}5000 \\
5000 \\
500 \\
500\end{array}$ \\
\hline $\begin{array}{l}\text { Bromide mixture } \\
\text { Chloropicrin and Methyl }\end{array}$ & None & 1500 \\
\hline $\begin{array}{l}\text { Chloride mixture } \\
\text { Cumene Hydroperoxide } \\
\text { Cyanogen } \\
\text { Cyanogen Chloride } \\
\text { Cyanuric Fluoride } \\
\text { Die:etyl Peroxide }\end{array}$ & $\begin{array}{c}\text { None } \\
80-15-9 \\
460-19-5 \\
506-77-4 \\
675-14-9\end{array}$ & $\begin{array}{r}1500 \\
5000 \\
2500 \\
500 \\
100\end{array}$ \\
\hline $\begin{array}{l}\text { (Concentration }>70 \%) \\
\text { Diazomethane } \\
\text { Dibenzoyl Peroxide } \\
\text { Diborane }\end{array}$ & $\begin{array}{c}110-22-5 \\
334-88-3 \\
94-36-0 \\
19287-45-7\end{array}$ & $\begin{array}{r}5000 \\
500 \\
7500 \\
100\end{array}$ \\
\hline
\end{tabular}


Dibutyl Peroxide (Tertiary)

Dichlora Acetylene

Dichlorosilane

Diethylzinc

Diisopropyl Peroxydicarbonate

Dilaluroyl Peroxide

Dimethyldichlrosilane

Dimethylhydrazine, 1,1-

Dimethylamine, Anhydrous

2,4-Dinitroaniline

Ethyl Methyl Ketone Peroxide

(also Methyl Ethyl Ketone

Peroxide; concentration

$>60 \%$

Ethyl Nitrite

Ethylamine

Ethylene Fluorohydrin

Ethylene Oxide

Ethyleneimine

Fluorine

Formaldehyde (Formalin)

Furan

Hexafluoroacetone

Hydrochloric Acid, Anhydrous

Hydrofluoric Acid, Anhydrous

Hydrogen Bromide

Hydrogen Chloride

Hydrogen Cyanide, Anhydrous

Hydrogen Fluoride

Hydrogen Peroxide $(52 \%$ by

weight or greater)

Hydrogen Selenide

Hydrogen Sulfide

Hydroxylamine

Iron, Pentacarbonyl

Isopropylamine

Ketene

Methacrylaldehyde

Methacryloyl Chloride

Methacryloyloxyethyl

Isocynate

Methyl Acrylonitrile

Methylamine, Anhydrous

Methyl Bromide

Methyl Chloride

Methyl Chloroformate

Methyl Ethyl Ketone Peroxide

(concentration $>60 \%$ )

Methyl Fluoroacetate

Methyl Fluorosulfate

Methyl Hydrazine

Methyl lodide

Methyl Isocyanate
110-05-4

7572-29-4

1109-96-0

557-20-0

105-64-6

105-74-8

75-78-5

57-14-7

124-40-3

97-02-9

1338-23-4

109-95-5

75-04-7

371-62-0

75-21-8

151-56-4

$7782-41-4$

50-00-0

$110-00-9$

684-16-2

7647-01-0

7664-39-3

10035-10-6

7647-01-0

74-90-8

7664-39-3

7722-84-1

7783-07-5

7783-06-4

7003-49-8

13463-40-6

75-31-0

463-51-4

78-85-3

920-46-7

30674-80-7

126-98-7

74-83-9

74-83-9

74-87-3

$79-22-1$

1338-23-4

453-18-9

421-20-5

60-34-4

74-88-4

624-83-9
5000

250

2500

10000

7500

7500

1000

1000

2500

5000

5000

5000

5000

100

5000

1000

1000

1000

500

5000

5000

1000

5000

5000

1000

1000

7500

150

1500

2500

250

5000

100

1000

150

100

250

2500

2500

15000

500

5000

100

100

100

7500

250 
Methyl Mercaptan

Methyl Vinyl Ketone

Methyltrichlorosilane

Nickel Carbonly (Nickel

Tetracarbonyl)

Nitric Acid $(94.5 \%$ by

weight or greater)

Nitric Oxide

Nitroaniline (para Nitro-

aniline

Nitromethane

Nitrogen Dioxide

Nitrogen Oxides (NO; NO2;

N204; N203)

Nitrogen Tetroxide (also

called Nitrogen Peroxide)

Nitrogen Trifluoride

Nitrogen Trioxide

Oleum ( $65 \%$ to $80 \%$ by

weight; also called

Fuming Sulfuric Acid)

Osmium Tetroxide

Oxygen Difluoride (Fluorine

Monoxide)

Ozone

Pentaborane

Peracetic Acid (concentra-

tion > 60\% Acetic Acid;

also called Peroxyacetic

Acid)

Perchloric Acid (concentra-

tion $>60 \%$ by weight)

Perchloromethyl Mercaptan

Sulfuric Anhdride (also

called Sulfur Trioxide)

Tellurium Hexafluoride

Tetrafluoroethylene

Tetrafluorohydrazine

Tetramethyl Lead

Thionyl Chloride

Trichloro (chloromethyl)

silane

Trichloro (dichlorophenyl)

Silane

74-93-1

79-84-4

5000

$75-79-6$

500

13463-39-3

150

7697-37-2

500

10102-43-9

250

100-01-6

5000

75-52-5

2500

10102-44-0

250

$10102-44-0$

250

10544-72-6

250

7783-54-2

5000

10544-73-7

250

8014-94-7

1000

20816-12-0

100

$7783-41-7 \quad 100$

10028-15-6 100

19624-22-7 100

$79-21-0$

1000

$7601-90-3$

5000

$594-42-3$

150

$7446-11-9$

1000

$7783-80-4$

250

116-14-3

5000

$10036-47-2$

5000

75-74-1

1000

$7719-09-7$

250

1558-25-4

2500

27137-85-5

2500

10025-78-2

5000

$79-38-9$

10000

Trifluorochloroethylene

2487-90-3

1500

"Chemical Abstract Service Number.

**Threshold Quantity in Pounds (Amount necesary to be covered by this standard). 
Table 2. Initial List of Extremely Hazardous Substances

ammonia

bromine

chlorine

ethylene oxide,

hydrogen chloride

hydrogen cyanide,

hydrogen fluoride

hydrogen sulfide,

methyl chloride

methyl isocyanate

phosgene

sulfur dioxide

sulfur troxide

toluene diisocyanate,

vinyl chloride 
Table 3. Guidelines for prevention of industrial accidents in less developed countries.

Establish an information base on safe handling of hazardous materials.

Charge industrial management with assessing risks, identifying means of reducing hazards, making periodic safety audits.

Scrap decaying, unproductive, unsafe industries.

Identify and draw up emergency preparedness plans for potential accident areas.

Include intrinsic safety in town planning and integrate plans for chemical emergencies in national disaster management policy.

Establish no-risk, light industry between hazardous zones and human settlements

Establish infrastructure for safety within industrial complexes and designate technical safety officers.

Use safe technological options in design, fabrication, installation, operation and maintenance.

Establish an inspection system with the capability of assessing hazard, evaluating risk and recommending appropriate action.

Develop the capability to evaluate toxicity of chemicals. 

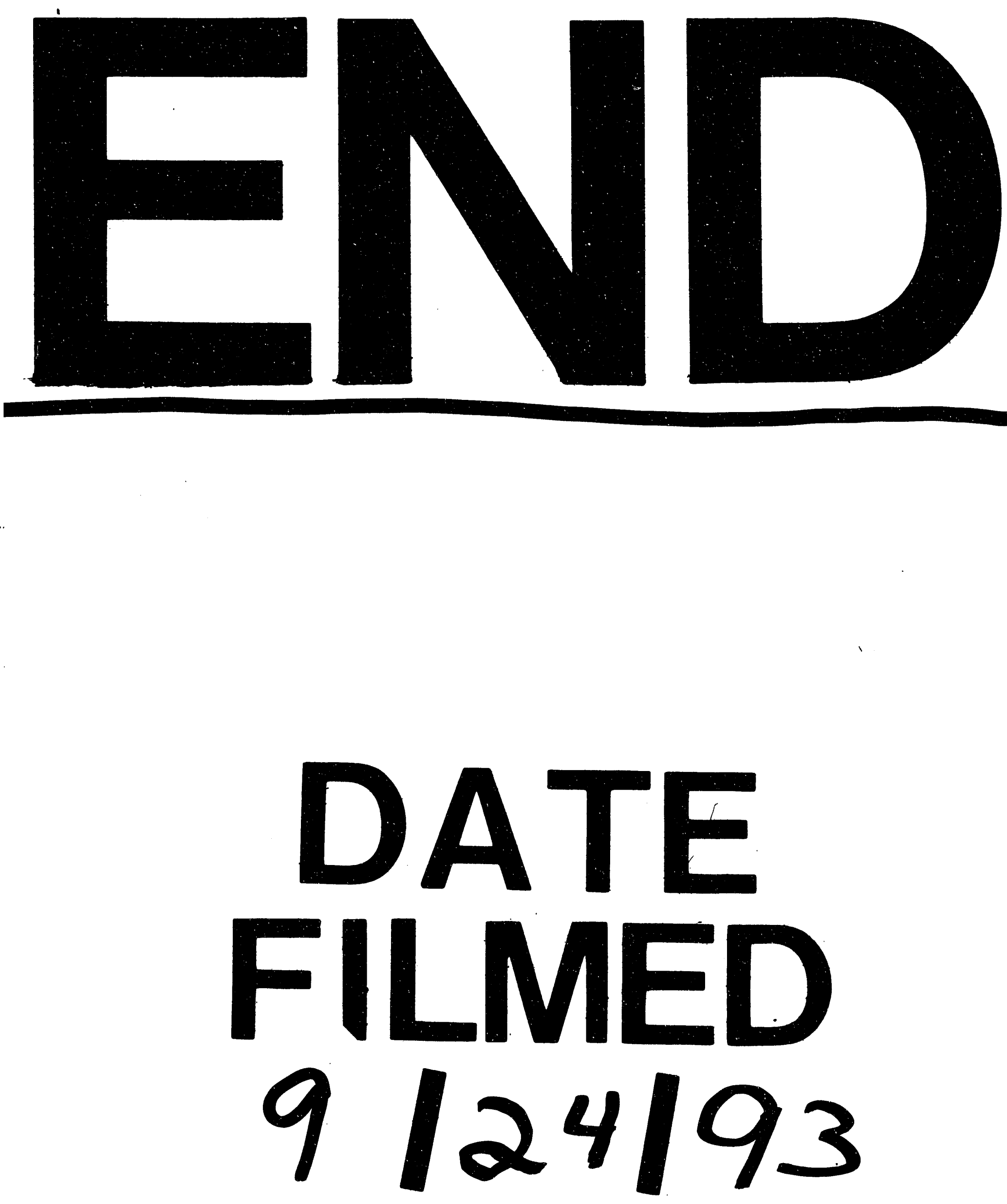
